\title{
Description of a new species of Carcinops (Coleoptera: Histeridae) from Cuba
}

\section{Описание нового вида Carcinops (Coleoptera: Histeridae) с Кубы}

\author{
Alexander V. Sokolov \\ Александр В. Соколов
}

Ltd. Service Aqua, Severniy bulvar, 12V, 84, Moscow 127490, Russia. E-mail: margarinotus@yandex.ru ООО «Сервис Аква», Северный бульвар, 12в, 84, Москва 127490, Россия.

KEY WORDS: Coleoptera, Histeridae, Dendrophilinae, Carcinops golovkoi, new species, Cuba.

КЛЮЧЕВЫЕ СЛОВА: Coleoptera, Histeridae, Dendrophilinae, Carcinops golovkoi, новый вид, Куба.

ABSTRACT. Description of new species of clownbeetles Carcinops golovkoi sp.n. from western Cuba is given. This is second new species of Histeridae collected in decaying stems of endemic and endangered cactus Dendrocereus nudiflorus (Engelmann ex Sauvalle) Britton et Rose, 1920.

РЕЗЮМЕ. Описывается новый вид Carcinops golovkoi sp.n. с западной Кубы. Это второй новый вид жуков-карапузиков, собранный в гниющих стеблях эндемичного и находящегося под угрозой исчезновения кактуса Dendrocereus nudiflorus (Engelmann ex Sauvalle) Britton et Rose, 1920.

\section{Introduction}

The genus Carcinops Marseul, 1855 includes more than 48 species [Mazur, 1997]. The majority of the species widely distributed in tropics of Central and South America, with only few species in southern of North America, northern Africa, southeastern Asia and Australia. They inhabit different decayed plant and animal substanses, founded under tree's bark, in bird's and mammal's nests. Most of the species uniformely black coloured, but several central and south american species have metallic green colour, frequently with bronze tinge [Marseul, 1855, 1862; Lewis, 1899]. During author's cuban trip in 2004 were collected green-coloured Carcinops, distinctly distinguished from similar species. The beetles were abundant in decayed stems of endemic and endangered cactus Dendrocereus nudiflorus (Engelmann ex Sauvalle) Britton et Rose 1920, together with other histerids, including before described remarkable Iliotona markushevae Sokolov, 2005. The new species is described and illustrated below. Illustrations were prepared with digital camera Canon EOS 40D. Measurements are abbreviated as follows: $\mathrm{L}$ - total length of pronotum and elytra, Lp - pronotal length, Le - length of elytron along elytral suture, $\mathrm{Wpb}$ - pronotal width across base, We - elytral width across humeri.

\section{Genus Carcinops Marseul, 1855}

\section{Carcinops golovkoi Sokolov sp. n.} Figs 1-8

MATERIAL. Holotype, $0^{\top}, 23^{\circ} 11^{\prime} \mathrm{N} 81^{\circ} 09^{\prime} \mathrm{E}$ W Cuba, Matanzas province, E end of Hicacos (Varadero) peninsula, 05-08.11.2003, A. Sokolov. Paratypes, 66 specimens, collected together with holotype. Holotype and 4 paratypes are deposited in collection of Zoological Institire RAS, Saint-Petersburg, other paratypes in author's collection.

DESCRIPTION. Habitus as illustrated (Figs 1-2). L=2.15 $\mathrm{mm}$. Body elongate-oval, moderately convex. Smooth and shining, metallic green with faint bronze tinge, with uniform fine sparse punctation. Legs and mouthparts pitch-brown, antennal club rufous. Head shining, finely and sparsely punctate. Frontal stria sharp, broadly interrupted medially. Supraorbital stria absent. Mandibles sharp, curved, with one acute middle tooth.

Pronotum strongly narrowed to front. $\mathrm{Lp}=0.75 \mathrm{~mm}$. Wpb= $1.37 \mathrm{~mm}$. Marginal pronotal stria complete laterally, anterior marginal stria not interrupted behind head, central portion feebly arcuate outwardly. In addition to shallow ground punctation numerous coarser lateral punctures present. There is unique small round antescutellar puncture, its diameter is about $1 / 6$ scutellum length.

Maximal elytral width at humeri, elytra slightly narrowed towards apex. $\mathrm{Le}=1.40 \mathrm{~mm}, \mathrm{We}=1.50 \mathrm{~mm}$. Elytron with apical transverse row of rather coarse and dense punctures. Elytral epipleura coarsely punctured, interspaces smooth, epipleural striae complete. Humeral stria thin but distinct. Outer subhumeral stria occupies $1 / 2-3 / 5$ elytral lenths and usually continues to humeri as a row of punctures. Inner subhumeral stria extends almost to apex. Dorsal striae strongly impressed, with deep strial punctures, $4-5^{\text {th }}$ and sutural striae look like punctured lines. Striae 1-4 complete, stria 5 usually complete, but divided into several fragments, arch toward scutellum. Sutural stria reaching almost 1/2, sometimes continues to $3 / 5$ the length by punctures. Propigidium coarsely and very densely punctured, without interspace between punctures, pygidial punctures only slightly smaller and sparser towards apex (Fig. 3).

Prosternal lobe rather densely punctured, shining, without marginal stria. Carinal striae of prosternal keel sharp, almost parallel, meeting anteriorly. Mesoventrite, metaven- 


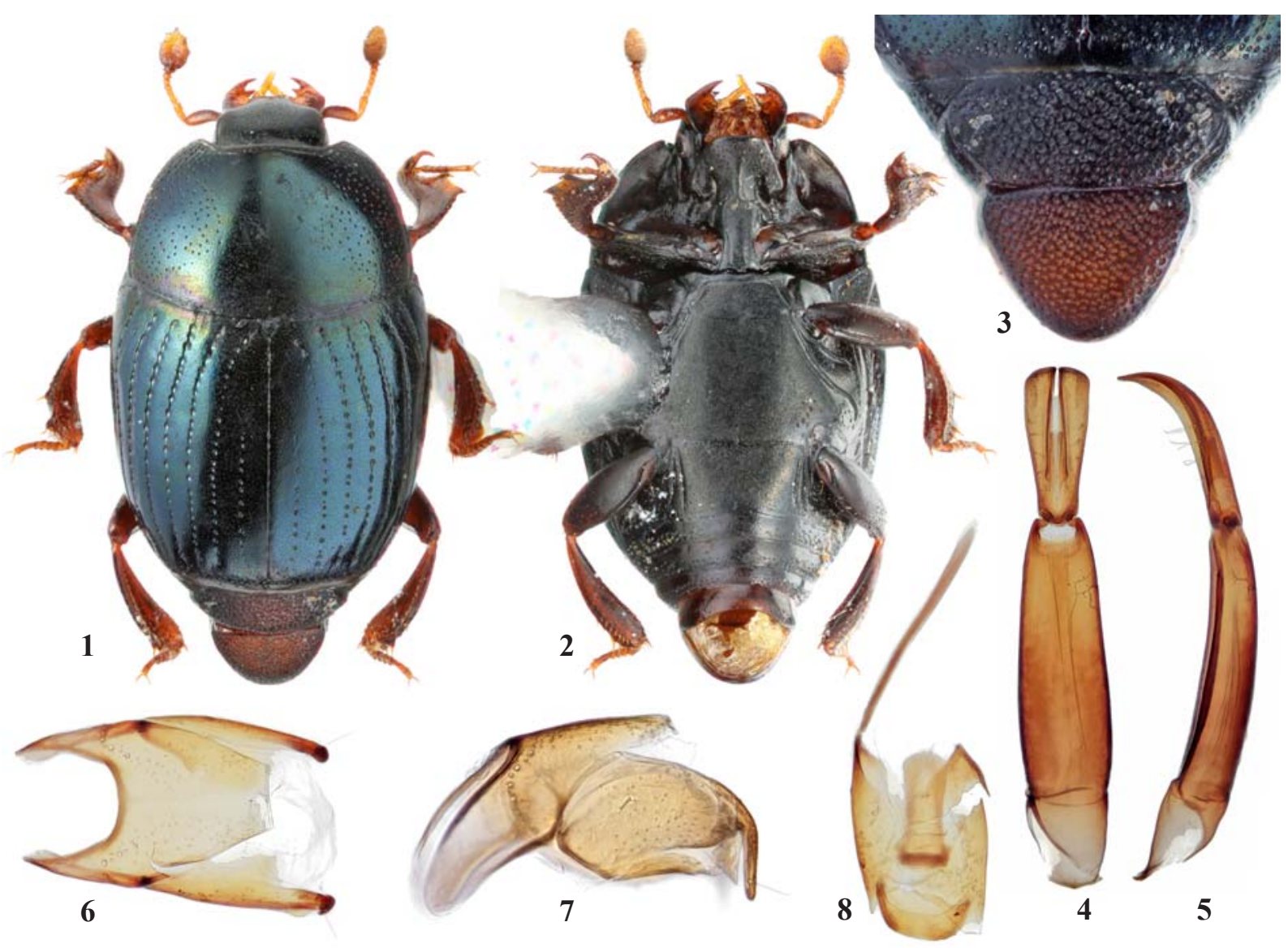

Figs 1-8. Carcinops golovkoi Sokolov, sp.n.: 1-2 - habitus; 3 - propygidium and pygidium; 4-8 - male genitalia; 4-5 - aedeagus; 6-7 - 8-th tergite and 8-th sternite; 8 - 9-th, 10-th tergites and 9-th sternite (spiculum gastrale); 1, 3-4, 6, 8- dorsal view; $2-$ ventral view; 5,7 - lateral view.

Figs 1-8. Carcinops golovkoi Sokolov, sp.n.: 1-2 - габитус; 3 - пропигидий и пигидий; 4-8 - гениталии самца; 4-5 - эдеагус; 6-7 - 8-й тергит и 8-й стернит; 8 - 9-й, 10-й тергиты и 9-й стернит (spiculum gastrale); 1, 3-4, 6, 8- сверху; 2 - снизу; 5, 7 - сбоку.

trite and disc of $1^{\text {st }}$ abdominal ventrite opaque, longitudinally microsculptured, with fine and sparse punctures. Metaventrite with several coarse sparse punctures near metacoxae. First and $2^{\text {nd }}$ abdominal ventrites coarsely and rather densely punctured laterally, other ventrites similarly punctulate throughout. Mesoventral marginal stria not interrupted. Mesometasternal suture absent, looks like a smooth line. Lateral metaventral stria sharp, prolong to metacoxae, incurved posteriorly. Outer and inner striae of $1^{\text {-st }}$ abdominal ventrite sharp, not quite reaching the $2^{\text {nd }}$ ventrite suture. Protibia with 2 strong teeth. Mesotibia with one spine near middle and two at the apex. Metatibia with two spines at the apex.

COMPARATIVE REMARKS. This species is similar to C. cribripuga Wenzel, 1944 by proportions and shape of body, as punctures of pronotum and pygidium. Differs from it by metallic-green color, abbreviated 6-th dorsal stria, denser and coarser propygidial and pygidial punctures. From similarly coloured species (C. bellula Marseul, 1862, C. cuprina Marseul, 1862, C. dominicana Marseul, 1855, C. prasina (Lewis, 1899) and C. viridicollis Marseul, 1855) differs by larger and more convex body, punctation of propygidium and pygidium and broadly interrupted frontal stria.

ETYMOLOGY. The new species is dedicated to my friend Vitaliy Golovko, who helped me a lot during joint tropical expeditions.

BIOLOGY. All specimens were collected near seashore in thorn forest on karst limestones. The beetles were founded inside decaying stems of endemic cactus Dendrocereus nudiflorus, together with some other histerids, i.e., Aeletes gulliver (Marseul, 1856), I. markushevae and Omalodes ruficlavis Marseul, 1853 [Sokolov, 2005].

ACKNOWLEGMENTS. I wish to thank Dr. K.V. Makarov for help with making photographs. Special thanks are due to Dr. A. K. Tishechkin for critical remarks.

\section{References}

Lewis G. 1899. On new species of Histeridae and notices of others // The Annals and Magazine of Natural History. Ser.7. Vol.4. P.18.

Marseul S. 1855. Essai monografique sur la famille des Histerides (Suite) // Annales de la Société entomologique de France. Ser.3. T.3. P.96-97.

Marseul S. 1862. Supplement a la monographie des Histerides (Suite) // Annales de la Société entomologique de France. Ser.4. T.2. P.15-16.

Mazur S. 1997. A world catalogue of the Histeridae (Coleoptera: Histeroidea) // Genus. Supplement. P.1-373.

Sokolov A. 2005. Additions to hister beetles (Coleoptera: Histeridae) fauna of Cuba, with description of new species of genus Iliotona Carnochan, 1917 // Russian Entomological Journal. Vol.14. No.1. P.83-85.

Wenzel R. 1944. On the classification of the histerid beetles // Fieldiana, zool. Vol.28. No.2. P.102-104. 